\title{
Simulation Calculations of Solidification and Cooling of Copper Alloy Casts
}

Jiří Machuta, Iva Nová

Faculty of Mechanical Engineering, Technical University of Liberec, Studentská 2, 46117 Liberec. Czech Republic. Email: jiri.machuta@tul.cz,iva.nova@tul.cz

The article deals with the simulation calculation of solidification and cooling of plate-shaped castings cast into metal and into sand mould about cavity dimensions $80 \times 80 \times 10 \mathrm{~mm}$. During the experiments were monitored conditions of filling, solidification and cooling in the die-cast (metal mould) and in the sand mould. Both about outer dimensions $120 \times 120 \times 80 \mathrm{~mm}$. Die-cast was made of steel 1.2343 (ČSN 19552) and the sand mould was prepared of green sand (bentonite). For the purpose of the experiment was used foundry simulation software MAGMA 5. For simulation calculations were used physical and thermo-physical quantities in dependence on temperature. Concurrently were used knowledges of the simulation calculations performed at our department, Department of Engineering Technology, Faculty of Mechanical Engineering - Technical University of Liberec.

Keywords: Simulation calculation, Cooper alloy, Transmission coefficient, Contact resistence.

\section{Acknowledgement}

This paper is published with the support of the project TUL SGS 21005.

\section{References}

[1] NOVÁ, I. (1986). Tepelné zpracování forem ze sádrových formovacích směsí, doctoral dissertation work. FSKSM, VŠST v Liberci, Czech Republic.

[2] GRIGORIEFF, R. D. (1972). Numerik gewöhnlicher Differentialgleichungen, Band 1. Teubner, Germany.

[3] RICHTER, W. (1986). Numerische Lösung partieller Differentialgleichungen mit der Finite Elemente-Methode, Vieweg Braunschweig. Germany.

[4] BEKER, M. (1986). Heat Transfer. A Modern Approach. Plenum Press N.Y., London.

[5] SCHWARTZ, H. R. (1986). Numerische Mathematik. Stuttgart, Germany.

[6] EXNER, J., NOVÁ, I. (2001). Influence of heat transfer conditions coeff. of gap in the casting-metal mould system. In: Archives of foundry, Volume 1, p. 94 to 102. Katowice, Poland.

[7] NOVÁ, I. (2002). Tepelné procesy ve slévárenských formách (Thermal processes in the casting moulds). 134 pages, ISBN 80-7083-662-8. Technical university of Liberec, Czech Republic.

[8] HORÁČEK, J. (2010). Measuring and simulation calculations field of temperature cast the shape of the plate. In: Conference Proceedings 7. International PhD conference and 47. Foundry days, ISBN 978-80-904020-6-5.

[9] HORÁČEK, J., NOVÁ, I. (2011). Simulační výpočty tuhnutí a chladnutí odlitků z litiny, In: Strojírenská technologie, No. 6, Vol. XVI, ISSN 1211-4162. Jan Evangelista Purkyně University in Ústí nad Labem, Czech Republic. 